\title{
Paradigmaváltás a fogmegtartó kezelésben: az amalgámkorszak vége
}

\author{
Mikulás Krisztina dr. ${ }^{1}$ - Linninger Mercedes dr. ${ }^{1}$ \\ Takács Emőke dr. ${ }^{1}$ - Kispélyi Barbara dr. ${ }^{1}$ - Nagy Katalin dr. ${ }^{2,3}$ \\ Fejérdy Pál dr. ${ }^{1,4}$ - Hermann Péter dr. ${ }^{1,4}$ \\ ${ }^{1}$ Semmelweis Egyetem, Fogorvostudományi Kar, Fogpótlástani Klinika, Budapest \\ ${ }^{2}$ Szegedi Tudományegyetem, Fogorvostudományi Kar, Szeged \\ ${ }^{3}$ Magyar Fogorvosok Egyesülete, Budapest \\ ${ }^{4}$ Szakmai Kollégium Fog- és Szájbetegségek Tagozata és Tanácsa, Budapest
}

\begin{abstract}
Az amalgámot már több mint 150 éve alkalmazzák a fogászatban kedvező mechanikai tulajdonságai és tartóssága miatt. Az amalgámtöméssel kapcsolatban számos kérdés merült fel a múltban, elsősorban higanytartalma kapcsán, amely globális viták tárgyát képezte. Az „amalgámkérdés” múltjának és jelenének bemutatásával közleményünk célja a nemzetközi irodalom jelenlegi álláspontjának ismertetése. A jelen összefoglaló a PubMed adatbázisban lévő publikációk, az Európai Fogorvosok Tanácsának irányelvei és a Szakmai Kollégium Fog- és Szájbetegségek Tagozatának ajánlásán alapul. Bár a fogászati amalgám használata széles körben elterjedt, és sok előnnyel jár, aggályok merültek fel az emberi egészségre és a környezetre való káros hatása miatt, amelyben a legfóbb problémát a higanynak a csatornahálózatba való bejutása jelenti a hulladékkezelés során. Az Európai Parlament és Tanács 2017 tavaszán fogadta el a Minamata-egyezményen alapuló, higanyra vonatkozó rendeletét, amelynek a fogászati amalgámot érintő pontjait részletesen taglalja a közlemény. Az Európai Unió tagállamainak nemzeti tervet kell készíteniük az amalgám kivezetésére, amelynek előkészítése minden országban egyéni sajátosságokra épül. Az ötvözet teljes kivezetése lassan, 2030ig valósul meg a szabályzat szerint. A szerzők az üvegionomer cementek és a műgyanta bázisú, esztétikus kompozitok ismertetése kapcsán tárgyalják a lehetséges amalgámalternatívák előnyös és hátrányos tulajdonságait. A jövőben számos anyagtani kutatás és hosszú távú követéses vizsgálat szükséges az ideális tömőanyag kifejlesztésére. Több egészségügyi világszervezet mellett az Európai Fogorvosok Tanácsa is felhívja a figyelmet a fogszuvasodás megelőzését elősegítő programokra, amelyek a restaurációk számának csökkentését javasolják.
\end{abstract}

Orv Hetil. 2018; 159(42): 1700-1709.

Kulcsszavak: amalgám, amalgámkivezetés, amalgámszeparátor, üvegionomer cement, kompozittömés

\section{Paradigm shift in conservative dentistry: the end of the amalgam era}

Dental amalgam has been used for more than 150 years due to its beneficial mechanical properties and durability in dentistry. In the past and to date, many questions about amalgam restorations have arisen, especially regarding the mercury content, which has been the subject of global disputes. By presenting the past and present of the 'amalgam issue', the aim of our paper is to display the current position of international literature. This summary is based on the publications in the PubMed database, the guidelines of the Council of European Dentists. Although the use of dental amalgam is widespread, concerns have been raised about the adverse effect on human health and the environment, focusing on its heavy metal pollution during waste treatment. In 2017, the European Union (EU) adopted the socalled Mercury Regulation, based on the United Nations Minamata Convention on Mercury, the recommendations of which are presented in the present review. This Regulation includes the requirement for EU Member States to develop a national action plan for the phase-down of amalgam. The feasibility plan for complete phase-out may be guaranteed by 2030 . The authors discuss the advantages and disadvantages of possible amalgam alternatives by presenting glass-ionomers and resin-based composites. In the future, more material research programmes and long-term follow-up studies are necessary. In addition to several global health organizations, the Council of European Dentists also draws attention to prevent dental caries, expecting to reduce the number of restorations.

Keywords: amalgam, amalgam phase-down, amalgam separator, glass-ionomer cement, composite restoration

Mikulás K, Linninger M, Takács E, Kispélyi B, Nagy K, Fejérdy P, Hermann P. [Paradigm shift in conservative dentistry: the end of the amalgam era]. Orv Hetil. 2018; 159(42): 1700-1709.

(Beérkezett: 2018. június 9.; elfogadva: 2018. július 30.) 


\section{Rövidítések}

$\mathrm{ART}=$ (atraumatic restorative treatment) atraumatikus konzerváló kezelés; ASDS = (American Society of Dental Surgeons) Amerikai Szájsebészek Társasága; BisDMA = biszfenolA-etoxilát-dimetakrilát; BPA $=$ biszfenol A; CED $=($ Council of European Dentists) Európai Fogorvosok Tanácsa; EFSA = (European Food Safety Authority) Európai Élelmiszerbiztonsági Hatóság; ENSZ = Egyesült Nemzetek Szervezete; EU = Európai Unió; FDI = (Federation Dentaire Internationale) Nemzetközi Fogászati Szövetség; GICs = (glass ionomer cements) üvegionomer cementek; HEMA = hidroxi-etil-metakrilát; $\mathrm{Hg}=$ elemi és szervetlen higany; $\mathrm{MeHg}=$ szerves és a leggyakrabban metilezett higany; NEAK = Nemzeti Egészségbiztosítási Alapkezelő; ROS = (reactive oxygen species $)$ reaktívoxigén-származékok; SCENIHR = (Scientific Committee on Emerging and Newly Identified Health Risks) Új és Újonnan Azonosított Egészségügyi Kockázatok Tudományos Bizottsága; TEGDMA = trietilén-glikol-dimetakrilát; UDMA = uretándimetakrilát; $\mathrm{WHO}=$ (World Health Organization $)$ Egészségügyi Világszervezet

Az emberi élettartam növekedése és a populáció egyre idősebbé válása miatt tartós, biokompatibilis anyagokra van szükség a fogászatban. A fogszuvasodás következtében a hiányzó fogszövetek és a fogak pótlására felhasznált anyagok mechanikai tulajdonságai, biokompatibilitása és adhéziója a fogszövetekhez általában nem tökéletes, további fejlesztésre szorul. A amalgám esetében ehhez hozzájárul a nem megfelelő esztétika, illetve a tömés behelyezése és az eltávolítása során a keletkezó veszélyes hulladék kezelése. 2013-ban az ENSZ Környezetvédelmi Programjában hangsúlyozta a higanynak az emberi szervezetre és az embert körülvevő környezetre gyakorolt káros hatását [1].

A amalgámot már több mint 150 éve alkalmazzák a fogorvoslásban a fogszuvasodás kezelésére, kedvező mechanikai tulajdonságai és tartóssága miatt. Ugyanakkor elkészítéséhez kiterjesztettebb preparálás szükséges a megfelelő retenció eléréséhez. Csökkenő felhasználási tendenciája nem esztétikus megjelenésével és higanytartalmával függ össze a leginkább [2]. Az amalgámtömések legfőbb összetevője (50\%-ban) az elemi higany [3]. Ismeretes, hogy a higany élelmiszerekben is előfordulhat szennyező anyagként. Míg az amalgámoknál az elemi és szervetlen higany $(\mathrm{Hg})$ felszabadulása jellemző, addig az ételekkel bevitt higany (fóként tengeri halak fogyasztása következtében) szerves és a leggyakrabban metilezett higany $(\mathrm{MeHg})\left(\mathrm{CH}_{3} \mathrm{Hg}^{+}\right)$formában jut be a szervezetbe és tovább a táplálékláncba [4]. Az Európai Élelmiszerbiztonsági Hatóság (European Food Safety Authority EFSA) 2012-ben az élelmiszerekben található szervetlen higany beviteli értékének felső tolerálható határát $4 \mu \mathrm{g}$ / testsúlykg/hét-ben határozta meg [5]. Az amalgámtömésből kioldódott higany mennyisége alacsony [6], és az élelmiszerrel bevitt $\mathrm{MeHg}$ előfordulásával összevetve ez a mennyiség korlátozott [4]. Higany nemcsak a fogászatban alkalmazott amalgámban található, de felszaba- dulhat még például az oltóanyagokból és az energiatakarékos izzólámpákból is [7]. A higany toxicitása az egész világot érintő probléma, hiszen számos neurológiai elváltozást, kognitív zavarokat és autoimmun betegségeket okozhat. A $\mathrm{MeHg}$ akkumulálódik a táplálékláncban, és a vér-agy gáton való átjutása miatt veszélyesebb, mint a szervetlen higany [7]. A szerves higany a leginkább az agykéregben okoz károkat, különösen a vizuális kéregben, a motoros és a szenzoros központokban. A krónikus elemihigany-mérgezés klinikai tünetei a bőrt és a központi idegrendszert érintik (például perifériás neuropathia, remegés, álmatlanság, memóriavesztés, érzelmi labilitás, depresszió, fejfájás, látászavarok) [7]. Az amalgámtömésekkel összefüggésben felmerülő mellékhatásokról - a neurotoxicitásról, a vesekárosodásról, a sclerosis multiplexról, a stroke-ról és a szív-ér rendszerrel összefüggő megbetegedésekről - szóló feltételezések nem igazolódtak be $[8,9]$. Kivételt jelentenek azok a ritka esetek, amikor allergiás reakció lép fel generalizál$\tan [10]$. Az amalgámtömések körül észlelhető oralis lichenoid laesio általában egyoldali megjelenésú lokális mellékhatás [11]. Európában évente 125 millió amalgámtömést távolítanak el. Az amalgámtömések készítésekor és eltávolításakor rövid idejű higanyfelszabadulás történik, amely nem észlelhető intakt amalgámtömések környezetében. A higanyfelszabadulás a fogorvost és a fogászatban dolgozó egészségügyi szakembereket fokozottabban érinti, ez azonban a nemzetközi közlemények alapján nincs egyértelmú összefüggésben a feltételezett mellékhatásokkal $[12,13]$.

Az EU különböző testületei által megfogalmazott javaslatok és állásfoglalások jelentősen különböztek az elmúlt időszakban az „amalgámkérdést” tekintve. A Nemzetközi Fogászati Szövetség (Federation Dentaire Internationale - FDI) már 2007-ben, az Egészségügyi Világszervezet (World Health Organization - WHO) pedig 2009-ben felhívta a figyelmet, hogy szükség van amalgámot helyettesító alternatívákra és a tömőanyagok széles körü fejlesztésére $[14,15]$. Az Európai Fogorvosok Tanácsa (Council of European Dentists - CED) 2016/17-ben az alábbi célokat, ajánlásokat szorgalmazta az Európai Parlamentben az amalgámötvözetekkel kapcsolatban.

- Csökkenteni kell a fogászati restaurációk (tömések) számát, ezen belül a leginkább az amalgámtömések arányát. Ennek érdekében olyan egészségvédelmi intézkedéseket kell hozni, amelyek a szájüreg egészségének fenntartását és a fogszuvasodás megelőzését szolgálják. Ez nemcsak a környezetvédelem szempontjából érdekes, hanem szociális és gazdasági előnyökkel is jár a társadalom és a páciensek számára, mivel az egészséges szájüreg a jó általános egészségi állapot alapvető feltétele.

- A CED az amalgám helyettesítésére anyagtani kutatásokat és olyan tömőanyagok fejlesztését javasolja, amelyek használata környezetkímélő és költséghatékony. 
- A CED támogatja az amalgám kivezetését. Az amalgámszeparátor és az amalgám kapszulázott formájának bevezetése elengedhetetlen a környezetvédelem szempontjából. Klinikai szempontból a megfelelő széli záródású és rágófelszínú amalgámtömések eltávolítása nem szükséges; csak abban az esetben javasolt, ha a páciens allergiás az ötvözet valamelyik összetevőjére. Elővigyázatosan kell eljárni várandós kismamáknál a fogászati anyagok felhasználásakor, ugyanúgy, mint bármilyen egyéb gyógyszer vagy orvosi beavatkozás esetén. Egy német tanulmány szerint az anyatejben található higany koncentrációja alacsonyabb amalgámtömés jelenlétében, mint halfogyasztást követően, illetve alacsonyabb vagy egyenlő a tehéntejben előforduló mennyiséggel [16].

Az Európai Unió 2017 májusában fogadta el a Minamata-egyezményen alapuló, úgynevezett 'higanyra vonatkozó szabályozást' [17], amelynek a fogászati amalgámot érintő pontjait „Az amalgám kivezetése” címú pontban tárgyalja közleményünk.

Az Európai Bizottság a kezdődő fogszuvasodás ellátására atraumatikus konzerváló kezelést (atraumatic restorative treatment - ART) javasol higanymentes anyagokkal [18], hangsúlyozva az üvegionomer cementek (glass ionomer cements - GICs) jelentőségét. Az üvegionomer cementek használata költséghatékony, környezetbarát, csökkenti a szekunder caries előfordulását, és segíti a dentin mineralizációját $[19,20]$. A páciensek esztétikai elvárásai mellett alapvető, hogy az anyag megválasztásakor annak mechanikai tulajdonságai és a funkcionális rehabilitáció legyen a legfontosabb kritérium. Már az 1980-as évektól megnőtt az igény a múgyanta alapú kompozit esztétikus tömések iránt nemcsak a frontfogak, hanem az őrlőfogak esetén is [21].

A NEAK (Nemzeti Egészségbiztosítási Alapkezelő) adatai alapján az elmúlt években jelentősen csökkent az újonnan készült amalgámtömések száma Magyarországon. Közleményünk célja, hogy bemutassa és összefoglalja az egész világot foglalkoztató „amalgámkérdés” és „amalgámháború” hátterét és jelenét [22], amelyek nagy hatással vannak a fogászati tömőanyagok felhasználására és folyamatos fejlesztésére. A higany fogászati amalgámban való felhasználása jelenti az Unióban a legnagyobb mértékű higanyfelhasználást. A tömés elkészítése és eltávolítása során a higany bekerül a csatornahálózatba, ezáltal jelentős környezetszennyező tényező. A 2017/852es EU-rendelet 2019. 01. 01-tôl kötelezővé teszi az amalgámszeparátorok használatát, 2030-ig pedig az amalgám teljes kivezetését [17]. A probléma valójában az összes fogászati rendelő́t érinti Magyarországon. A cikk bemutatja az EU állásfoglalását a fogászati amalgámokra vonatkozóan, és az amalgámot helyettesítő plasztikus tömőanyagok tulajdonságait. Nem utolsósorban a legfrissebb fejlesztések is említésre kerülnek az utolsó fejezetben, amelyek új bioaktív anyagok bevezetésére irányulnak.

\section{Módszer}

Közleményünk az Európai Fogorvosok Tanácsának (Council of European Dentists - CED) irányelvein, a Szakmai Kollégium Fog- és Szájbetegségek Tagozatának ajánlásán, valamint a MEDLINE (PubMed) adatbázisban található publikációkon alapul. Az irodalomkutatás elektronikus úton történt. Az adatbázisban a következő keresőszavakat és kombinációkat alkalmaztuk: „fogászati amalgám” („dental amalgam”), „amalgámtoxicitás” (,amalgam toxicity”), „múgyanta alapú kompozitok” („resin composite”), „üvegionomer cementek” („glassionomer cements"), amalgám-, kompozit- és üvegionomercement restaurációk tartóssága („durability of amalgam, composite, glass-ionomer cement restorations"), illetve „fogászati anyagok biokompatibilitása” („biocompatibility of dental materials"), amelyekre összesen 48916 hivatkozást találtunk. Ebből kiválasztottunk 50 releváns, magasan citált közleményt, amelyeket a szakterületen belül a legfontosabbnak ítéltünk meg. A keresés során a fogorvosi irodalomból angol vagy magyar nyelvü teljes szövegközleményeket, szisztematikus összefoglalókat, randomizált kontrolltanulmányokat és összehasonlító utánkövetéses vizsgálatokat válogattunk be 1990-től 2018. 03. 24-ig. Az összehasonlító vizsgálatokból kizártuk azokat a cikkeket, amelyek kevesebb, mint hároméves utánkövetésről számoltak be. Összefoglalónkban három, nemcsak az orvostársadalom, hanem a közvélemény érdeklődését is a leginkább érintő kérdéskört vizsgáltunk.

1. A fogászati amalgám.

2. Az amalgám kivezetése.

3. Az amalgámot helyettesítő plasztikus tömőanyagok: az üvegionomer cementek, a műgyanta alapú kompozitok (ormocerek, kompomerek) és a bioanyagok fejlesztése, jövője.

\section{A fogászati amalgám}

A fogszuvasodás az egész világon elterjedt krónikus betegség, amelynek kezelése globálisan jelentős kihívást jelent a közegészségügyben [23]. A fogszuvasodás a keményszövet demineralizációs és remineralizációs ciklusainak eredőjeként alakul ki, amelyben az elváltozás eleinte reverzibilis, majd a mélybe hatolva irreverzibilis roncsolódást okoz. Ha a demineralizációs folyamatok kerülnek elötérbe, a fog szövetei károsodnak, és kezelés nélkül a folyamat fogelvesztéshez is vezethet. A fogszuvasodás krónikus betegség, amely megelózhetô. A szájüregi egészség terén elért nagyszerú eredmények ellenére a fogszuvasodás még mindig nagyon komoly problémát jelent a fejlődő országokban, ahol az iskoláskorú gyermekek $60-90 \%$-át és a felnőtt lakosság nagy részét is érinti [23]. A caries kezelése magában foglalja a páciens fogszuvasodásra való rizikójának felmérését, a prevenciót, a reverzibilis caries ellátását és lehetóleg a restauratív fázis (a tömések vagy egyéb fogpótlások elkészítése) ki- 
tolását. Ha a fogszövetek károsodása visszafordíthatatlan, a leggyakrabban alkalmazott módszer a szuvasodás eltávolítása, az üreg tisztítása és a direkt restauráció elkészítése, amely helyreállítja a fog formáját és funkcióját.

A fogszuvasodás ellátására már az 1830-as években az amalgámot kezdték használni. A leggyakrabban alkalmazott amalgámötvözetek általában 40-70\% ezüstöt, 50\% elemi higanyt, $12-30 \%$ ónt, $12-24 \%$ rezet, $0-4 \%$ indiumot és elenyésző mennyiségű ( $1 \%$ ) cinket és $0,5 \%$ palládiumot tartalmaznak [24]. A konvencionális amalgám megkeverése során az ezüstből és ónból álló gamma-fázis ( $\gamma$-fázis) kapcsolatba kerül a higannyal, és két új fázis keletkezik: az ezüstből és higanyból álló $\gamma_{1^{-}}$, illetve az ónból és higanyból álló $\gamma_{2}$-fázis [25]. A réztartalom alapján megkülönböztetünk alacsony (2-5\%) réztartalmú konvencionális és magas (12-30\%) réztartalmú, gamma2-fázis-mentes amalgámokat [3]; mindkét esetben fennáll a kémiai és az elektrokémiai korrózió veszélye, amely nemcsak a tömésben lévő repedések mentén, hanem a plakkal borított tömés felszínén is létrejöhet [25].

A fogászati amalgám számos összetevője közül a higanytartalom miatt tört ki az „amalgámháború”. A biológiai káros hatások megítélése már a kezdetektől fogva nem egységes. A higany inhalációval, bőrrel való érintkezéssel, táplálékkal és a placentán keresztül juthat be az emberi szervezetbe [7]. Az amalgámtömésekből a higanyleadás a reakcióba nem lépett higany párolgásával, illetve a $\gamma_{1}$-fázis fokozatos átalakulásával van összefüggésben. A felszabaduló mennyiséget a rágás, a fogmosás, a parafunkciók, a korrózió és más fémötvözetek jelenléte (elektrokémiai korrózió) emelheti meg, amelynek mértéke függ a szájüregben lévő amalgámtömések számától, az életidejüktől, a tömések felületének nagyságától és nem utolsósorban a fogcsikorgatástól (stresszkorrózió) [26]. A nyálból a tápcsatornába kerülő és felszívódó higany mennyisége alacsony [6]. A felszabaduló higany koncentrációjának értékét a vérben, a vizeletben és a hajban mérik [4]. Nicolae és mtsai vizsgálataiban a kanadai lakosság vizeletében mért higany koncentrációja 0,12 és $0,31 \mu \mathrm{g} / \mathrm{L}$ között volt, ami az egészségre káros értéknél szignifikánsan alacsonyabb. Mellékhatások $7 \mu \mathrm{g} / \mathrm{L}$ koncentrációnál fordulhatnak elő [27]. A táplálékból felszívódó szerves higany értéke a hatszorosa a már megkötött amalgámtömésekből felszabaduló szervetlen higany felszívódásának [27]. A tömések készítése és eltávolítása során higanygőz keletkezik, amelynek egy része belélegezve a tüdőbe kerül, majd a véráramba jut. Az eltávolított amalgámtömések számától és az eltávolítás módjától (például a vízhưtés alkalmazásától, az elszívás minőségétől, a kofferdamizolálás, azaz a gumilepedő segítségével történő abszolút izolálás jelenlététől) nagymértékben függ a higanyfelszabadulás, ami átmenetileg kimutatható a páciensek, a fogorvosok és az asszisztensek vizeletében. A nagyobb higanyterhelésnek kitett fogászatban dolgozók szervezetében magasabb a higanykoncentráció, mint az átlagpopulációban [12]. A fogorvosok hajában szignifikánsan magasabb szervetlenhigany-koncentrációt
(>5 ppb) mutattak ki, amely azonban szintén nem érte el a veszélyesnek minősített koncentrációt [13]. Természetesen a mérések nem egyértelmúen tükrözik a valós higanykoncentrációt a szervezetben, mivel az sok tényezőtől függ. A higanyfelszabadulás mérésekor a szerves és a szervetlen higany koncentrációját mérik együttesen, ahol nehéz különbséget tenni a táplálékból, illetve a fogászati amalgámból származó higany között. Sherman és mtsai javasolták a Hg-izotóp alkalmazását a mérések során, amelynek segítségével meg lehet különböztetni a halfogyasztásból származó szerves higanyt $(\mathrm{MeHg})$ és az amalgámból származó elemi higanyt $\left(\mathrm{Hg}_{(\mathrm{g})}^{0}\right)$. Vizsgálataikban a vizeletből kimutatható higany nagy része a halfogyasztásból származott [4]. A MeHg gyorsan eljut a tápcsatornából a véráramba, majd a vér-agy gáton és a placentán átjutva komoly központi idegrendszeri károsodást, illetve fejlődési rendellenességet okozhat, főleg magzatkorban és az újszülötteknél [28]. A szervetlen $\mathrm{Hg}$ is okozhat központi idegrendszeri elváltozásokat és vesekárosodást [28], ez elsődlegesen inhalációval kerül be elemi formában a szervezetbe higanygőz formájában $\mathrm{Hg}_{(\mathrm{g})}^{0}$. A higanygőz belégzése előfordulhat például az iparban, az aranybányászatban, és a szájüregben is felszabadulhat a tömésekből, de az utóbbi esetben ennek a mennyisége alacsony [28]. A belélegzett $\mathrm{Hg}_{(\mathrm{g})}^{0} 80 \%$-a bekerül a véráramba, és gyorsan oxidálódik a sejtekben. Az oxidálódott szervetlen $\mathrm{Hg}$ nagy része a vesébe kerül, és kiválasztódik a vizeletbe [29]. Mivel a vizeletbe a $\mathrm{Hg}$ nagyrészt szervetlen formában kerül be, a vizeletben mért $\mathrm{Hg}(>98 \%)$ a $\mathrm{Hg}_{(\mathrm{g})}^{0}$ kimutatására alkalmazott biomarker [28].

Az elmúlt évtizedekben számos epidemiológiai vizsgálat foglalkozott a kérdéssel, hogy az amalgámból felszabaduló higany károsíthatja-e az idegrendszert, a vesét, az immunrendszert, a légzőszerveket, a vérkeringést, a tápcsatornát és a szaporító szervrendszert [29]. Bates és mtsai közleményükben összegezték, hogy alacsony evidenciájúak az eredmények a krónikus általános megbetegedések gyakorisága és az amalgámrestaurációk között [3]. Az immunrendszerre vonatkozóan szintén nincs bizonyíték arra, hogy az amalgámtömésekből felszabaduló higany autoimmun betegséget okoz [3]. Melchart és mtsainak 4787 páciens bevonásával készített tanulmánya nem talált szignifikáns összefüggést a panaszok intenzitása, a tüneteket hordozó páciensek és az amalgámtöméssel ellátott felszínek száma között [30]. Az amalgámötvözetek szisztémás hatásai közül a központi idegrendszerre és a szív- és érrendszerre való káros hatása sem igazolódott be $[8,31]$. Az amalgámtömések azonban okozhatnak lokális mellékhatásokat, például kontakt dermatitist, oralis lichenoid elváltozásokat [11]. Az amalgámtömések eltávolítása után jelentős javulás volt megfigyelhető azoknál a pácienseknél, akiknek a bőrpróbája is pozítiv volt amalgámra és higanyra [11]. Komoly veszélyt jelenthet a higany azok számára, akik higanyallergiában szenvednek. Ennek előfordulása szerencsére nagyon ritka, szükség esetén bőrpróbával lehet igazolni 
[29]. Ugyanakkor az amalgámtömésekből kioldódó higany mennyisége a modern ötvözeteknél nagyon alacsony, és messze az érvényes egészségügyi határérték alatt van $[6,27]$.

Az amalgám használata és sikerességi aránya jól dokumentált az irodalomban, költséghatékony tömőanyagnak számít a kisőrlő- és őrlőzóna ellátásában. Ha hosszú távon figyelemmel kísérjük a költségek eloszlását, és figyelembe vesszük az amalgám-, a kompozit- és az üvegionomercement tömések élettartamában rejlő különbségeket, akkor Sjögren és mtsai kalkulációja szerint egy II. osztályú üreg ellátásában a 10 éves becsült költség 189,80 USD amalgámtömésnél, míg 363,70 USD kompozittömésnél és 224,90 USD üvegionomer cementeknél [32]. A Cochrane adatbázisában Rasines Alcaraz és mtsai metaanalízise 10 közlemény alapján hasonlított össze 3265 kompozittömést és 1935 amalgámtömést maradó őrlőfogak esetén. A szerzők hangsúlyozzák, hogy a mügyanta alapú kompozitok esetén több hiba fordul elö, és magasabb a kockázat szekunder caries kialakulására, mint az amalgámtöméseknél, az eredmények azonban alacsony evidenciájúak, ezért további hosszú távú követéses vizsgálatokat javasolnak a legmodernebb fejlesztésű kompozitokkal és a legújabb technikákkal, múszerekkel [33].

\section{Az amalgám kivezetése}

A higany nehézfém, a természetben elemi, szervetlen és szerves formában fordul elő [34]. Ezeknek a formáknak a toxicitása eltérő, és egymásba átalakulhatnak [34]. A higany elemi formában csak kismértékben mérgező, szerves vegyületei azonban annál inkább, ami világszerte jelentôs veszélyt jelent az emberi egészségre, az ökoszisztémára és az élővilágra. A higanykibocsátás és a kapcsolódó expozíciós kockázatok jelentős részét emberi tevékenység okozza. Az Unióban jelentkező összes higanylerakódás 40-80\%-a az Unión kívülrôl ered. Ebból adódóan helyi, regionális, nemzeti és nemzetközi szintû fellépésre van szükség [17]. Az emberi szervezetbe jelentős mennyiségű higany kerülhet be a tengeri halak fogyasztása során (nagyrészt metil-higany és ritkábban szervetlen higany formájában) és kismértékben a fogászati amalgámból (a tömés behelyezésekor és eltávolításakor a higanygőzból és a csatornarendszeren keresztül) $[28,34]$.

Az amalgámötvözetek tárgyalásakor nem szabad szem elől téveszteni, hogy az amalgám az egyik legjobban ismert tömőanyag. Míg felhasználása számos országban csökkent, addig a világ másik részén még mindig az egyedüli tömőanyag-választási lehetőségnek számít [2]. A felhasználás csökkenése a higanykioldódás miatti aggodalomnak és a nem esztétikus megjelenésnek tudható be. A higanyt tartalmazó termékek eltávolítása során a környezetre való káros hatás és a népegészségre való haszon/előny közötti egyensúly megbomlása miatt született meg a Minamata-egyezmény. Az Európai Unió 2017 májusában fogadta el a Minamata-egyezményen alapuló, úgynevezett 'higanyra vonatkozó szabályozást' [17]. „A rendelet a higany, a higanyvegyületek és a higanykeverékek felhasználására és tárolására, valamint kereskedelmére, a hozzáadott higanyt tartalmazó termékek gyártására és felhasználására, valamint kereskedelmére, továbbá a higanyhulladék kezelésére vonatkozó intézkedéseket és feltételeket állapít meg annak érdekében, hogy biztosított legyen az emberi egészség és a környezet magas szintü védelme a higany és a higanyvegyületek antropogén eredetû kibocsátásaival szemben” [17]. „A higany fogászati amalgámban való felhasználása jelenti az Unióban a legnagyobb mértékü higanyfelhasználást, és ez jelentős szennyezőforrás is. Ezért az egyezménnyel és különösen az egyezmény A mellékletének II. részében felsorolt intézkedéseken alapuló nemzeti tervekkel összhangban a fogászati amalgám használatát fokozatosan csökkenteni kell” [17]. A szabályzat tartalmazza a tagországok felhívását saját nemzeti program kidolgozására, amely a fogászati amalgám teljes kivezetésének tervét ismerteti. Ennek alapvető feltétele, hogy a projektek jól tervezettek legyenek, és a fogorvosok bevonásával készüljenek. Az Európai Parlament és a Tanács (EU) 2017/852-es rendeletének 10. cikke a következő pontokat tartalmazza.

- A fogászati amalgámot csak előre adagolt, kapszulázott kiszerelésben lehet felhasználni 2019. 01. 01-től.

- Tejfogakba, 15 év alatti gyermekeknél, várandós kismamáknál és a laktációs időszakban 2018. 07. 01-től tilos amalgámot alkalmazni a fogászati kezelés során, kivéve, ha azt a fogorvos az adott beteg esetében egészségügyi okokat figyelembe véve kifejezetten szükségesnek tartja.

- 2019. 07. 01-ig a tagállamoknak nemzeti tervet kell kidolgozniuk az amalgám használatának fokozatos csökkentése érdekében, annak kivezetésére.

- 2019. 01. 01-től kötelező az amalgámszeparátorok bevezetése minden olyan fogorvosi rendelőbe, ahol fogászati amalgámot használnak fel, amalgámtömést vagy ilyet tartalmazó fogat távolítanak el. Az amalgámszeparátor kiválasztja és összegyújti az amalgámrészecskéket, a szennyvízbe kerülő részecskéket is beleértve.

- 2021. 01. 01-től a használatban lévő összes amalgámszeparátornak 95\%-os visszatartási hatékonysági szintet kell biztosítania az amalgámpartikulumok tekintetében.

- A fogorvosoknak biztosítaniuk kell amalgámhulladékuknak - beleértve az amalgámmaradványokat és -részecskéket, valamint a fogászati amalgámmal szenynyezett fogtöméseket és fogakat vagy azok darabjait engedélyezett hulladékgazdálkodási intézmény vagy vállalkozás általi kezelését és összegyűjtését.

- Az amalgám teljes kivezetése valószínúleg folyamatosan és lassan, lehetőleg 2030-ig valósul meg, figyelembe véve az EU tagállamainak eltérően kivitelezhető terveit. 
A WHO hangsúlyozza, hogy az amalgám elhagyása az alternatívák minőségi fejlesztésétől függ. Az adhezív fogászat a leggyorsabban fejlődő és változó területe a fogorvoslásnak, és ez nagy valószínúséggel az elkövetkező évtizedben is fontos kérdés marad, ezért szükség van átfogó tanulmányokra a kompozitok biokompatibilitását tekintve [35]. Fontos megjegyezni, hogy Magyarországon, ahol még amalgámot használnak, az nagyrészt nem a kapszulás kiszerelés, hanem a kézi keverésü változat. A keverés során higanygőz keletkezik, amely ellen védelmet nyújthat a kapszulázott kiszerelés, ha az tökéletesen záródik. Az amalgámtömés kondenzálásakor, a polírozásnál és a restaurációk eltávolításánál is javasolt vízhütést, elszívót és kofferdamizolálást alkalmazni. Higanygőz keletkezhet a helytelenül tárolt és fel nem használt amalgámmaradék esetében is. A fogorvosi rendelőből többféle módon kerülhet higany a környezetbe. A szellőztetés során a levegőbe, az amalgámtömés eltávolításakor keletkező szennyvízzel pedig a csatornahálózatba. Az amalgámszeparátorok alkalmazásával nagymértékben csökkenthető a vizekbe jutó higany mennyisége [36].

A magyarországi fogorvosi ellátásban nem az amalgám kivezetése okoz majd komoly nehézséget, hanem az amalgámszeparátorok kötelező bevezetése. A Szakmai Kollégium Fog- és Szájbetegségek Tagozata egyértelmüen támogatja az EU által kitüzött 2030-as céldátumot az amalgámkivezetés szempontjából. A Szakmai Kollégium Fog- és Szájbetegségek Tagozatának korábbi javaslata szerint racionálisabb lett volna az amalgám korábbi kivezetése (például 2022 végén), míg az új rendelők építésekor az amalgámszeparátorok kötelező telepítését már 2019-től vezette volna be. Az amalgámszeparátor minden rendelőre kiterjedő kötelező telepítését 2030-ra javasolta volna kitolni a Szakmai Kollégium Fog- és Szájbetegségek Tagozata. Ez azért is lett volna optimális, mert eddig az időpontig szinte magától végbement volna az összes rendelőben a fogászati egységkészülékek cseréje, ami már az új szabályozásnak megfelelően amalgámszeparátorral lett volna ellátva. Így ez kevésbé sújtaná a fogorvosi praxisokat Magyarországon. Ezt a véleményt azonban a 2017/852-es EU-rendelet felülírta 2017 májusában [17]. A 2017/852-es rendelet 2018. 07. 01-től bevezetendő szabályozásának az amalgámra vonatkozó, „kivételes” felhasználásának hátterében a kompozitokban előforduló monomer okozta allergiás reakciók állhatnak. Ez kiküszöbölhető lenne az üvegionomer cementek és a kerámiaszemcséket tartalmazó ormocerek alkalmazásával. Az ormocerek szignifikánsan kevesebb monomer, például uretán-dimetakrilát (UDMA), trietilén-glikol-dimetakrilát (TEGDMA) kioldódását mutatják, mint a kompozitok [37].

\section{$\mathrm{Az}$ amalgámot helyettesítő alternatívák}

A fogászati tömőanyagokat csoportosíthatjuk az elkészítésük módja alapján. Az indirekt restaurációkat a fogtechnikus a fogtechnikai laboratóriumban a mintán ké- szíti el, míg a direkt restaurációkat a fogorvos készíti a szék mellett. Az indirekt restaurációk anyagai lehetnek például nemesfém ötvözetek, kerámiák és kompozitok; a direkt tömőanyagok közé tartoznak az amalgámok, az üvegionomer cementek, a mügyantával módosított üvegionomer cementek, a múgyanta bázisú kompozitok, a kompomerek és az ormocerek. Számos fémötvözet és esztétikus kerámia érhetó el az indirekt restaurációkhoz, amelyek hosszú távú megoldást nyújtanak, azonban nagyon költségesnek számítanak. Véleményünk szerint az indirekt eljárások nem váltják ki a direkt eljárásokat magas költségeik miatt, fooleg a közfinanszírozott rendelőkben, ugyanis ez irreális költségeket róna a páciensekre a finanszírozott eljárásokkal szemben. Közleményünk a direkt restaurációk anyagait, az amalgámot helyettesítő plasztikus tömőanyagokat mutatja be.

\section{Az üvegionomer cementek létjogosultsága az amalgámok belyett}

Az üvegionomer cementek por és folyadék komponensének összekeverésével háromfázisú sav-bázis reakció következik be, amelynek során az anyag megkeményedik; kalcium-, alumínium- és fluoridionok lépnek ki, amikor a sav reagál az üvegrészecskékkel. Az ionok leadása a reakció után is folytatódik, és függ a környező kémhatástól. A felszabaduló fluoridionok remineralizációs hatásúak, a zománcba beépülve megelőzhetik a szekunder caries kialakulását $[19,20]$. Az üvegionomer tömések nagy előnye, hogy kémiailag kötnek a fog felszínéhez, továbbá a térfogatuk nem változik a kötési folyamat során, kivéve a fényre kötő változatoknál [19]. A tömőanyag hidrofil, nedvességtürő, a restauráció elkészítése kevésbé technikaszenzitív. A hagyományos üvegionomer cementekhez a szilárdságuk fokozására metakrilát múgyanta bázist adtak hozzá $[19,38]$, vagy magas viszkozitású üvegionomer cementeket és fényre kötő felületi lakkokkal kombinált termékeket javasolnak a tömések elkészítéséhez, amelyek magasabb hajlítószilárdsággal rendelkeznek, és kopásállóbbak, mint a hagyományos üvegionomercement restaurációk [20,38].

A magas viszkozitású üvegionomer cementek használata a minimálinvazív, atraumatikus restauratív kezelési technikánál (például a preventív célú barázdazárás vagy az egyfelszínú tejfog restauratív célú tömése stb.) tölt be fontos szerepet [19]. Ennek a minimálinvazív beavatkozásnak az a célja, hogy megelőzze a szuvas laesiók kialakulását, illetve azok mélyebbre terjedését a dentinbe. További célja, hogy a dentin szuvas laesióit minimálinvazív úton állítsa helyre. Kielbassa és mtsai a rendelkezésre álló irodalom alapján összefoglalják, hogy a mügyanta bázisú lakkal bevont üvegionomercement tömések alkalmazása ígéretes amalgámalternatívaként szolgálhat [20, 39]. Egyre több prospektív klinikai összehasonlító vizsgálat is megjelent a közelmúltban a különböző magas viszkozitású cementek és a különböző nanorészecsketöltöttségű, műgyanta alapú védőlakkok kapcsán, ame- 
lyek sikeres eredményekről számolnak be [19, 38]. A jelenlegi eredmények biztatóak, azonban további összehasonlító vizsgálatok szükségesek a magasabb evidenciájú eredmények miatt [20]. Gyakran felvetődik a kérdés az amalgámok helyettesítésére alkalmazott anyagoknál, hogy milyen költségtöblettel járnak. Goldman és mtsai az amalgámtömések és az ART-technikával készült magas viszkozitású üvegionomer cementek költséghatékonyságát vizsgálták, ahol az utóbbiak minimális költségnövekedést okoztak [40].

\section{A mügyanta bázisú kompozitok}

A fogászatban a magas esztétikai és funkcionális követelményeknek megfelelve széles körben alkalmazzák a kompozitokat a fog caries, fraktúra és erózió okozta, megbomlott szöveti struktúrájának élethű helyreállítására. A kompozíciós tömőanyagok szerves mügyanta mátrixból, szervetlen töltőanyagokból (például kvarc, kerámia, lítium-alumínium-szilikát-részecskék stb.) és a kettő közötti kötést biztosító szilánfázisból állnak [41-43]. A mátrix viszkózus monomereket tartalmaz, mint például hidroxi-etil-metakrilát (HEMA), uretán-dimetakrilát (UDMA), trietilén-glikol-dimetakrilát (TEGDMA), amelyek közül a TEGDMA-ra jellemző a legmagasabb kioldódás [42, 43]. A kompozitok az elmúlt időben jelentős fejlődésen mentek keresztül, azonban biokompatibilitásuk megkérdőjelezhető, hiszen a mai napig nem megoldott a tökéletes polimerizáció, aminek következménye a mechanikai és a kémiai degradáció $[41,43]$. Az inkomplett polimerizációnak köszönhetően a fent említett anyagokból residualis monomerek szabadulnak fel mikrogramm mennyiségben a pulpában és a nyálban, kapcsolatba lépve a szájüregi szövetekkel, majd továbbjutnak a gastrointestinalis rendszerbe, szisztémásan a vérben való jelenlétük azonban nem detektálható [41]. A TEGDMA a fó monomer, amely az adhezívekből és a kompozitokból kioldódva befolyásolhatja a sejtek metabolikus állapotát, DNS-károsodást, apoptózist és nekrózist okozhat in vitro [43]. Ezek a hatások nagyrészt a TEGDMA hatására bekövetkező megnövekedett reaktívoxigén-származékok (ROS) képzésével vannak összefüggésben [43]. A TEGDMA a légzési láncban a Komplex I-en fejt ki gátló hatást, ami megmagyarázza az irodalomban említett TEGDMA hatásait a redoxhomeosztázisra, a sejtek apoptózisára és a nekrózisra [44]. Mivel a kompozitok sok különböző alkotóelemből állnak, nagyon nehéz megítélni a toxicitásukat, amelyet az irodalomban in vitro körülmények között vizsgáltak gingivalis fibroblastokon a legtöbb esetben. A biszfenol-A-etoxilát-dimetakrilátot (BisDMA) tartalmazó mügyanta bázisú kompozitokból a hidrolitikus és enzimatikus folyamatok következtében BPA (4,40-dihidroxi-2,2-difenilpropán) és metakrilsav oldódik ki a nyálba [45]. Ez általában a tömések elkészítése utáni 24 órában történik meg, utána egészen kis mennyiségben folyamatosan szabadulhat még fel [45]. Az EFSA 2015-ben $4 \mu \mathrm{g} /$ testsúly kg/nap ideiglenes BPA-felszabadulást határozott meg kritikus határértéknek a szájüregben, amely a vesében elváltozásokat okozhat [29]. Az Új és Újonnan Azonosított Egészségügyi Kockázatok Tudományos Bizottsága (Scientific Committee on Emerging and Newly Identified Health Risks - SCENIHR) „A biszfenol A biztonságossága az orvosi eszközökben" című összefoglalójában (2015) leírja, hogy a fogászati anyagból hosszú távon felszabaduló BPA mennyisége alatta van a tolerálható értéknek, és elhanyagolható egészségügyi mellékhatásokkal jár (EFSA) [29]. A monomerek és a kompozitok számos összetevője esetén felmerül az allergia szerepe a káros hatások hátterében, előfordulásuk azonban nagyon ritka. A szabad monomerek előfordulása az emberi szervezetben azonban elenyésző koncentrációjú, és nem mutaható ki szisztémás káros hatás [29].

A legjobb anyag kiválasztása az anatomikus forma és funkció helyreállításában nagy kihívás a fogorvoslásban. A fogászati kompozitok egyre népszerúbb restauratív anyagok [42], mivel kiemelkedő esztétikát és megfelelő mechanikai ellenálló képességet nyújtanak a konzervatív terápiában. A kompozitok széles körű elterjedésében fontos szerepe van az adhezív technikának is, hiszen kevesebb fogszövet eltávolítása szükséges a retenció biztosításához. A több mint 40 éve alkalmazott kompozitok jelentős fejlődésen mentek keresztül, és mechanikai tulajdonságaik nagymértékben javultak. A kompozittömések legfőbb hátránya az amalgámhoz képest a polimerizációs zsugorodás és a tömés készítése során és utána kioldódó műgyanta monomerek felszabadulása, amelyek együttesen szekunder carieshez és töréshez vezethetnek [42]. A kompozitrestauráció elkészítése az amalgáméhoz képest technikaszenzitívebb [21, 42]. Kevés hosszú távú összehasonlító vizsgálat áll rendelkezésre a kompozittömések tartósságáról más tömőanyagokkal összehasonlítva, amit sok tényező határoz meg. A nemzetközi irodalomban számos közlemény támasztja alá, hogy az amalgámtömések tartósabbak (átlagos élettartamuk 6-16 év), mint a kompozittömések (5-7 év) [46]. Ezzel ellentétben Opdam és mtsai, valamint Palotie és mtsai a hátsó őrlőfogakba készített kompozittömések esetén az amalgáméhoz hasonló sikerességet figyeltek meg [21, 47]. Az elmúlt időszakban az őrlőfogakba készülő nagyméretű, múgyanta alapú kompozittömések készítésének egyszerüsítése és felgyorsítása érdekében a gyártók olyan „bulk-fill”, fényre kötő tömőanyagokat állítottak elö, amelyek egy rétegben aplikálhatók az üregbe, és egy lépésben megvilágíthatók. Használatuk során időt lehet megspórolni a tömés elkészítésekor, emiatt csökkenteni lehet a technikaérzékenységet. Mechanikai és esztétikai tulajdonságaik azonban nem tökéletesek, és élettartamuk sem olyan hosszú, mint az amalgámoké. A felhasználás szempontjából a közlemény szerzői megfelelőnek tartják a „bulk-fill” kompozitok használatát elsősorban a NEAK által finanszírozott rendelőkben, ahol ezenkívül fontos amalgámalternatívák lehetnek a páciensek ellátásában a műgyantával megerősített üvegionomer cementek is [48]. 


\section{Megbeszélés}

Az „amalgámháború” 1843-ban kezdődött az Amerikai Egyesült Államokban, New Yorkban, amikor az Amerikai Szájsebészek Társasága (American Society of Dental Surgeons - ASDS) bejelentette, hogy az amalgám használata veszélyes a páciensek és a fogorvosok egészségére a higanymérgezés lehetősége miatt [22]. Az elemi, a szerves és a szervetlen higany toxikus az emberi szervezetre és a kísérleti állatokra. A toxicitás foka a higany formájától függ. A fogászati amalgámmal kapcsolatos problémák két csoportra oszthatók. Az amalgámmal kapcsolatos legnagyobb veszély az amalgámtömések eltávolítása a szekunder caries vagy csonkfelépítés miatt, mivel ilyenkor a higany a tömések eltávolításával a fogászati kezelőegységen keresztül a csatornarendszerbe jut. A fogászati rendelőből kikerülő higanynak a környezetre való káros hatása kevésbé vitatott. A páciensekre gyakorolt hatást illetően az elvégzett vizsgálatok során nem sikerült semmilyen összefüggést találni az egyes tünetek, betegségek és a szájban meglévő amalgámtömések között [8-10, 30, 31], csak allergia esetén vet fel az alkalmazása problémákat.

Magyarországon és világszerte is az amalgám kivezetése jelenti a legfóbb nehézséget, amelyre a Minamataegyezmény ad iránymutatást, és 2019. 01. 01-től teszi kötelezővé az EU-ban az amalgámszeparátorok bevezetését a fogorvosi rendelőkbe. 2019. 01. 01-től a fogorvosok nem használhatnak fel higanyt ömlesztett formában, csak kapszulázott kiszerelésben. Korábbi véleményünknek helyet adva szeretnénk hangsúlyozni, hogy Magyarországon az amalgámszeparátorok kötelező bevezetése nagy terhet ró a fogorvosi rendelőkre, fóleg a NEAK által finanszírozott egységekre, ugyanis az amalgám kivezetésekor nemcsak az amalgámszeparátorok telepítéséről kell gondoskodni, hanem az egész csatornahálózatot át kell építeni, hogy az amalgám kivezetése megfeleljen az EU-szabályozásnak. Az újonnan készülő amalgámtömések száma nagymértékben csökkent az elmúlt évtizedekben a betegek esztétikai igénye miatt Magyarországon. A kompozitok indikációs területe a frontfogaktól egészen a molaris fogakig terjed, ahol fontos szerepet játszanak az amalgám alternatívájaként [46, 47]. Az anyag további előnyeihez sorolható az esztétikai megjelenés, az anatómiai forma élethû visszaállítása és a javíthatóság. Az amalgámot alapvetően fokozatosan felváltja a kompozittömés, habár sok klinikai tanulmány és retrospektív vizsgálat különböző állásponton van ma a kérdést illetően, hogy melyik a leggyakrabban használt anyag a konzerváló fogászatban. A kompozitokat 40 éve alkalmazzák a fogászatban, ezért jóval kevesebb irodalmi adat áll rendelkezésre a hosszú távú utánkövetéses vizsgálatokból, illetve a mellékhatásokat tekintve, mint az amalgámról. A legtöbb beszámoló in vitro kutatást mutat be a kompozitok esetében, ezért több in vivo követéses vizsgálatra és ezek fényében a tömőanyagok további fejlesztésére van szükség. Opdam és mtsai olyan összeha- sonlító tanulmányok és követéses vizsgálatok készítését javasolják, amelyek 2-3 évnél hosszabb utánkövetéssel rendelkeznek, hiszen a szekunder caries előfordulása, amely a restaurációk sikertelenségének legfőbb oka, a leginkább ennyi idő elteltével fordul elő [49].

Jelenleg nem létezik tökéletes anyag az amalgám helyettesítésére. A legutóbbi években olyan kutatások kerültek előtérbe az adhezívek és esztétikus tömőanyagok fejlesztésében, amelyek a mügyanta formula fejlesztését, a töltőanyag összetételét, a kötésidő redukálását, a magasabb fokú polimerizáció elérését és a fogszövetek gyógyítómechanizmusát támogató hatást célozzák meg [35]. Olyan bioaktív anyagok fejlesztése várható, amelyek számos kedvező funkcióval rendelkezhetnek majd: gátolhatják a bakteriális biofilm képződését, elősegíthetik a zománc és dentin remineralizációját, a pulpaszövet, a csont és a lágy szövetek regenerációját [49].

Az 1 és 100 nm közötti nanorészecskéknek a természetben való előfordulása gyakori, számos termékben fordulnak elő a hétköznapokban. A fogászati anyagoknál ezek a nanorészecskék az anyagba beágyazva fordulnak elő, javítva az anyag tulajdonságait. Nagyarányú felszabadulásuk jellemző például a fogtechnikai labori folyamatoknál, illetve a fogászati kezelés során. Schmalz és mtsai összefoglaló közleményükben felhívják a figyelmet ezeknek a nanorészecskéknek a lehetséges mellékhatásaira, amelyek fő célszerve a tüdő. Több kutatásra hívják fel a figyelmet, különösen a sérülékeny csoportok, például asztma vagy krónikus obstruktív tüdőbetegség esetén. Minden esetben javasolt az említett folyamatok során a vízhütés alkalmazása és a szellőztetés [50].

A klinikai vizsgálatok esetében az intraoralis, digitális lenyomatot készítő szkennelőfejek segítségével a restaurált fogakról készülő felvételek a jövőben lehetővé teszik az objektív minőségi követéses vizsgálatokat több független kutató bevonásával [49]. A jövő sok ígéretes, izgalmas új fejlesztést ígér. Közleményünk betekintést nyújt a fogorvoslásban használatos restauratív anyagok világába, amelyek Magyarországon a ma népbetegségnek számító caries gyógyításában nagyon fontos szerepet játszanak. Fel szeretnénk hívni a figyelmet az amalgám részleges és teljes kivezetésének fontosságára és az új bioaktív tömőanyagok fejlesztésére. A prevenciós programok, a betegek edukációja és a rendszeres kontrollvizsgálatok nagymértékben csökkentik a fogszuvasodás előfordulását. Ezért az amalgámkivezetés tervezetében és programjában feltétlenül komoly hangsúlyt kell szentelni ezeknek a szempontoknak.

\section{Következtetés}

Az amalgám kivezetése a környezetvédelem szempontjából nagyon fontos tényező, amelyet a 2017/852-es EUdirektíva szabályoz, és megvalósulása 2030-ra várható. Az EU összes tagállamának részletes programot kell kidolgoznia az amalgám teljes kivezetésére, az adott ország egyéni sajátosságainak megfelelően. A szabályozás 
2019. 01. 01-től kötelezővé teszi az amalgámszeparátorok bevezetését és az amalgám kapszulázott kiszerelésú alkalmazását. A CED, a WHO, az FDI és számos szervezet olyan egészségvédelmi programok bevezetését javasolja, amelyek a fogszuvasodás megelőzését és a fogászati restaurációk számának csökkentését célozzák meg. A jövőben további széles körű anyagtani kutatások, tömőanyag-fejlesztések és hosszú távú követéses vizsgálatok javasoltak.

Anyagi támogatás: A közlemény megírása, illetve az ehhez kapcsolódó kutatómunka anyagi támogatásban nem részesült.

Szerzői munkamegosztás: M. K.: Forrásmunka, az adatok és az eredmények feldolgozása, a kézirat megírása. L. M.: Kiegészítő forrásmunka mellett a cikk szerkesztésében és tartalmi javításában vett részt. T. E.: Forráskutatás, szerkesztés. K. B.: A kézirat tartalmi javítása. N. K.: A kézirat tartalmi javítása. F. P.: A kézirat korrektúrázása. H. P.: A kézirat tartalmi korrekciója, kiegészítő forráskutatás. A cikk végleges változatát valamennyi szerző elolvasta és jóváhagyta.

\section{Érdekeltségek: A szerzőknek nincsenek érdekeltségeik.}

\section{Irodalom}

[1] United Nations Environment Programme (UNEP). Global Mercury Assessment 2013: Sources, Emissions, Releases and Environmental Transport. UNEP Chemicals Branch, Geneva, Switzerland. Available from: https://wedocs.unep.org/bitstream/ handle/20.500.11822/7984/-Global\%20Mercury\%20Assessment-201367.pdf? sequence $=3 \&$ isAllowed $=y \quad$ [accessed: March $2,2018]$

[2] Mitchell RJ, Koike M, Okabe T. Posterior amalgam restorations - usage, regulation, and longevity. Dent Clin North Am. 2007; 51: 573-589.

[3] Bates MN. Mercury amalgam dental fillings: an epidemiologic assessment. Int J Hyg Environ Health 2006; 209: 309-316.

[4] Sherman LS, Blum JD, Franzblau A, et al. New insight into biomarkers of human mercury exposure using naturally occurring mercury stable isotopes. Environ Sci Technol. 2013; 47: 34033409

[5] Scientific Opinion on the risk for public health related to the presence of mercury and methylmercury in food. EFSA J. 2012; 10: 2985.

[6] Björkman L, Sandborgh-Englund G, Ekstrand J. Mercury in saliva and feces after removal of amalgam fillings. Toxicol Appl Pharmacol. 1997; 144: 156-162.

[7] Bjørklund G, Dadar M, Mutter J, et al. The toxicology of mercury: current research and emerging trends. Environ Res. 2017; 159: 545-554.

[8] Bates MN, Fawcett J, Garrett N, et al. Health effects of dental amalgam exposure: a retrospective cohort study. Int J Epidemiol. 2004; 33: 894-902.

[9] Eyeson J, House I, Yang YH, et al. Relationship between mercury levels in blood and urine and complaints of chronic mercury toxicity from amalgam restorations. Br Dent J. 2010; 208: E7; discussion: 162-163.
[10] McGivern B, Pemberton M, Theaker ED, et al. Delayed and immediate hypersensitivity reactions associated with the use of amalgam. Br Dent J. 2000; 188: 73-76.

[11] Laine J, Kalimo K, Happonen RP. Contact allergy to dental restorative materials in patients with oral lichenoid lesions. Contact Dermatitis 1997; 36: 141-146.

[12] Nagpal N, Bettiol SS, Isham A, et al. A review of mercury exposure and health of dental personnel. Saf Health Work 2017; 8: $1-10$.

[13] Wijesekara LA, Usoof R, Gamage SS, et al. Mercury levels in hair samples of dentists: a comparative study in Sri Lanka. J Investig Clin Dent. 2018; 9: e12302.

[14] FDI Policy Statement. Safety of Dental Amalgam adopted by the FDI General Assembly, 2007. https://www.fdiworlddental. org/sites/default/files/media/images/Safety-of-dental-amalgam-2007.pdf [accessed: March 2, 2018].

[15] Future use of materials for dental restoration: Report of the meeting convened at WHO HQ, Geneva, Switzerland, 16th to 17th November 2009. WHO, Geneva, 2010. http://www.who. int/oral_health/publications/dental_material_2011.pdf [accessed: March 2, 2018]

[16] Schmalz G, Arenholt-Bindslev D. Biocompatibility of dental materials. Springer Verlag, Berlin, Heidelberg, 2009; pp. 2-3, $71-72$.

[17] Regulation (EU) $2017 / 852$ of the European Parliament and of the Council of 17 May 2017 on mercury, and repealing Regulation (EC) No 1102/2008 (Text with EEA relevance.) [Az Európai Parlament és a Tanács (EU) 2017/852 rendelete [2017. május 17.] a higanyról és az 1102/2008/EK rendelet hatályon kívül helyezésérôl (EGT-vonatkozású szöveg).] Az Európai Unió Hivatalos Lapja L 137/1-21. Available from: https://eur-lex. europa.eu/legal-content/HU/TXT/PDF/?uri=CELEX:32017 R0852\&from $=\mathrm{HU}$ [accessed: March 2, 2018]. [Hungarian]

[18] BIO Intelligence Service. Study on the potential for reducing mercury pollution from dental amalgam and batteries. Final report prepared for the European Comission - DG ENV (2012), Contract Number 07.0307/2011/59114/SER/C3, 2012. http://ec.europa.eu/environment/chemicals/mercury/pdf/final_report_110712.pdf [accessed: March 2, 2018].

[19] Türkün LS, Kanik Ö. A prospective six-year clinical study evaluating reinforced glass ionomer cements with resin coating on posterior teeth: quo vadis? Oper Dent. 2016; 41: 587-598.

[20] Kielbassa AM, Glockner G, Wolgin M, et al. Systematic review on highly viscous glass-ionomer cement/resin coating restorations (Part II): do they merge Minamata Convention and minimum intervention dentistry? Quintessence Int. 2017; 48: 9-18.

[21] Opdam NJ, Bronkhorst EM, Loomans BA, et al. 12-year survival of composite vs. amalgam restorations. J Dent Res. 2010; 89: 1063-1067.

[22] Rathore M, Singh A, Pant VA. The dental amalgam toxicity fear: a myth or actuality. Toxicol Int. 2012; 19: 81-88.

[23] Petersen PE, Lennon MA. Effective use of fluorides for the prevention of dental caries in the 21 st century: the WHO approach. Community Dent Oral Epidemiol. 2004; 32: 319-321.

[24] Letzel H, van 't Hof MA, Marshall GW, et al. The influence of the amalgam alloy on the survival of amalgam restorations: a secondary analysis of multiple controlled clinical trials. J Dent Res. 1997; 76: 1787-1798.

[25] Fazekas Á. Conservative dentistry and endodontics. [Megtartó fogászat és endodoncia.] Semmelweis Kiadó, Budapest, 2006; pp. 50-52. [Hungarian]

[26] Berglund A. Estimation by a 24-hour study of the daily dose of intra-oral mercury vapor inhaled after release from dental amalgam. J Dent Res. 1990; 69: 1646-1651.

[27] Nicolae A, Ames H, Quiñonez C. Dental amalgam and urinary mercury concentrations: a descriptive study. BMC Oral Health $2013 ; 13-44$. 
[28] Clarkson TW, Vyas JB, Ballatori N. Mechanisms of mercury disposition in the body. Am J Ind Med. 2007; 50: 757-764.

[29] SCENIHR (Scientific Committee on Emerging and Newly Identified Health Risks) Opinion on The safety of dental amalgam and alternative dental restoration materials for patients and users. The SCENIHR adopted this opinion at the 10th plenary meeting on 29 April 2015. Available from: https://ec.europa.eu/ health/sites/health/files/scientific_committees/emerging/ docs/scenihr_o_046.pdf [accessed: March 2, 2018].

[30] Melchart D, Wühr E, Weidenhammer W, et al. A multicenter survey of amalgam fillings and subjective complaints in non-selected patients in the dental practice. Eur J Oral Sci. 1998; 106: 770-777.

[31] Ahlqwist M, Bengtsson C, Lapidus L. Number of amalgam fillings in relation to cardiovascular disease, diabetes, cancer and early death in Swedish women. Community Dent Oral Epidemiol. 1993; 21: 40-44.

[32] Sjögren P, Halling A. Survival time of Class II molar restorations in relation to patient and dental health insurance costs for treatment. Swed Dent J. 2002; 26: 59-66.

[33] Rasines Alcaraz MG, Veitz-Keenan A, Sahrmann P, et al. Direct composite resin fillings versus amalgam fillings for permanent or adult posterior teeth. Cochrane Database Syst Rev. 2014; 3: CD005620

[34] Clarkson TW, Magos L. The toxicology of mercury and its chemical compounds. Crit Rev Toxicol. 2006; 36: 609-662.

[35] Ferracane JL, Hilton TJ, Stansbury JW, et al. Academy of Dental Materials guidance - Resin composites: Part II - technique sensitivity (handling, polymerization, dimensional changes). Dent Mater. 2017; 33: 1171-1191.

[36] Batchu H, Rakowski D, Fan PL, et al. Evaluating amalgam separators using an international standard. J Am Dent Assoc. 2006; 137: 999-1005.

[37] Polydorou O, König A, Hellwig E, et al. Long-term release of monomers from modern dental-composite materials. Eur J Oral Sci. 2009; 117: 68-75.

[38] Klinke T, Daboul A, Turek A, et al. Clinical performance during 48 months of two current glass ionomer restorative systems with coatings: a randomized clinical trial in the field. Trials 2016; 17: 239.

[39] Kielbassa AM, Glockner G, Wolgin M, et al. Systematic review on highly viscous glass-ionomer cement/resin coating restorations (Part I): do they merge Minamata Convention and mini- mum intervention dentistry? Quintessence Int. 2016; 47: 813823.

[40] Goldman A, Frencken JE, De Amorim RG, et al. Replacing amalgam with a high-viscosity glass-ionomer in restoring primary teeth: a cost-effectiveness study in Brasilia, Brazil. J Dent. 2018; 70: 80-86.

[41] Hume WR, Gerzina TM. Bioavailability of components of resinbased materials which are applied to teeth. Crit Rev Oral Biol Med. 1996; 7: 172-179.

[42] Ferracane JL. Resin composite - state of the art. Dent Mater. 2011; 27: 29-38.

[43] Krifka S, Spagnuolo G, Schmalz G, et al. A review of adaptive mechanism in cell responses towards oxidative stress caused by dental resin monomers. Biomaterials 2013; 34: 4555-4563.

[44] Mikulás K, Hermann P, Gera I, et al. Triethylene glycol dimethacrylate impairs bioenergetic functions and induces oxidative stress in mitochondria via inhibiting respiratory Complex I. Dent Mater. 2018; 34: el66-el81.

[45] Atkinson JC, Diamond F, Eichmiller F, et al. Stability of bisphenol A, triethylene-glycol dimethacrylate, and bisphenol A dimethacrylate in whole saliva. Dent Mater. 2002; 18: 128-135.

[46] Sunnegårdh-Grönberg K, van Dijken JW, Funegård U, et al. Selection of dental materials and longevity of replaced restorations in Public Dental Health clinics in northern Sweden. J Dent. 2009; 37: 673-678.

[47] Palotie U, Eronen AK, Vehkalahti K, et al. Longevity of 2- and 3 -surface restorations in posterior teeth of 25- to 30-year-olds attending Public Dental Service - a 13-year observation. J Dent. 2017; 62: 13-17.

[48] Chesterman J, Jowett A, Gallacher A, et al. Bulk-fill resin-based composite restorative materials: a review. Br Dent J. 2017; 222: 337-344.

[49] Opdam NJM, Collares K, Hickel R, et al. Clinical studies in restorative dentistry: new directions and new demands. Dent Mater. $2018 ; 34: 1-12$.

[50] Schmalz G, Hickel R, van Landuyt KL, et al. Scientific update on nanoparticles in dentistry. Int Dent J. 2018 May 22. doi: 10.1111/idj.12394. [Epub ahead of print]

(Mikulás Krisztina dr., Budapest, Szentkirályi u. 47., 1088 e-mail: mikulas.krisztina@dent.semmelweis-univ.hu)

\section{"Lex posterior derogat priori." \\ (A későbbi törvény semmissé teszi az elöbbit.)}

A cikk a Creative Commons Attribution-NonCommercial 4.0 International License (https://creativecommons.org/licenses/by-nc/4.0) feltételei szerint publikált Open Access közlemény, melynek szellemében a cikk nem kereskedelmi célból bármilyen médiumban szabadon felhasználható, megosztható és újraközölhető, feltéve, hogy az eredeti szerző és a közlés helye, illetve a CC License linkje és az esetlegesen végrehajtott módositások feltüntetésre kerülnek. 